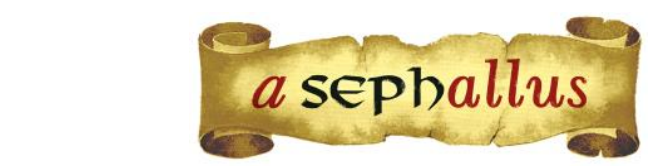

Revista aSEPHallus de Orientação Lacaniana

Núcleo Sephora de Pesquisa sobre o Moderno e o Contemporâneo

ISSN $1809-709 \mathrm{X}$

O crime: sobre o sentimento de culpa no homem e na mulher ${ }^{1}$

Vanessa Teixeira dos Santos

Mestre em Psychologie (Psychanalyse et recherches interdisciplinaires) pela Université Paris-Diderot (Paris, França) e em Teoria Psicanalítica pela Universidade Federal do Rio de Janeiro/UFRJ (Rio de Janeiro, Brasil) Graduada em Psicologia pela Universidade Federal do Rio de Janeiro/UFRJ (Rio de Janeiro, Brasil)

E-mail: vanessasantos.psi@gmail.com

Resumo:O objetivo do presente artigo é de realizar uma reflexão do ponto de vista psicanalítico sobre a diferença no número de mulheres e de homens que cometem crimes, um índice em geral maior entre os homens. A partir da noção de Freud e Lacan sobre o crime enquanto busca de um alívio do sentimento de culpa inconsciente pelos desejos de parricídio e incesto através de crimes e punições reais, pretendemos discutir as diferenças na formação do sentimento de culpa na mulher e no homem. Para tal, discutimos os caminhos do complexo de Édipo na menina e no menino e propomos que, como a menina passa por este processo de forma diferente, a mulher pode cometer menos crimes.

Palavras-chave: crime; sentimento de culpa; feminino.

Le crime: sur la culpabilité chez l'homme et chez la femme :Le but de cet article est de mener une réflexion psychanalytique sur la différence du nombre de femmes et d'hommes qui commettent des crimes, un indice généralement plus élevé chez les hommes. Depuis la notion de crime chez Freud et chez Lacan comme la recherche du soulagement de la culpabilité des désirs parricides et incestueux par de vrais crimes et punitions, nous avons l'intention de discuter des différences dans la formation de la culpabilité chez les femmes et chez les hommes. Nous discutons, alors, des voies du complexe d'ECdipe chez la fille et chez le garçon et nous proposons qu'une fois que la fille vit ce processus différemment, la femme peut commettre moins de crimes.

Mots-clés: crime; culpabilité; feminité.

Crime: about the sense of guilt in men and women:The purpose of this article is to carry out a psychoanalytical reflection on the difference in the number of women and men who commit crimes, a generally higher index among men. From Freud and Lacan's notion of crime as the search for relief from the unconscious sense of guilt of parricide and incest through real crimes and punishments, we intend to discuss the differences in the formation of the sense of guilt in women and in men. For this, we discuss the paths of the Oedipus complex for the girl and for the boy and propose that, as the girl goes through this process differently, the woman she will become may commit fewer crimes.

Keywords: crime; sense of guilt; the feminine. 


\title{
O crime: sobre o sentimento de culpa no homem e na mulher
}

\author{
Vanessa Teixeira dos Santos
}

No estudo da criminologia, não raro nos deparamos com a discrepância entre o número de crimes cometidos por homens e por mulheres, sendo os primeiros geralmente responsáveis pela maioria expressiva destes atos ilícitos, nos mais variados países e culturas. No Brasil, de acordo com o Infopen Mulheres, um levantamento de informações penitenciárias do Ministério da Justiça, a população carcerária masculina é muito maior do que a feminina, que representava apenas $6,4 \%$ do total de detentos em 2014. Também há estudos como o do Escritório das Nações Unidas sobre Drogas e Crimes (UNODC), publicado em 2014, que aponta que 95\% dos assassinos do mundo são homens, mas estes também são as maiores vítimas dos assassinatos. A violência contra a mulher e o chamado feminicídio, problemas tão comuns na sociedade atual, também fazem parte deste quadro de crimes cometidos por homens em sua maioria.

Como poderíamos, então, pensar esta diferença entre homens e mulheres na incidência de crimes em geral à luz da psicanálise e da noção de inconsciente? Para responder a esta pergunta, partiremos de um recorte psicanalítico do crime e de suas ramificações inconscientes, seguido de uma reflexão sobre as diferenças entre o complexo de Édipo masculino e feminino que possam influenciar nos mecanismos psíquicos que levam ao crime. Mas a que nos referimos quando usamos este termo?

No Dicionário da Língua Portuguesa Aurélio, o termo crime é definido como: "Violação da lei penal; delito" (Ferreira, 2008, pp. 170). Já o Dicionário Online Michaelis define crime como "1. Violação dolosa ou culposa da lei penal; 2 . Violação das regras que a sociedade considera indispensáveis à sua existência; 3. Infração moral grave; delito" (CRIME, 2012).

Observamos que nas definições de crime em dois dos principais dicionários da Língua Portuguesa, ele é visto como uma transgressão da lei, uma infração a um código de regras, seja ele penal ou moral, que deve ser seguido pelos integrantes de uma sociedade. Tal infração deve ser punida por lei, ou deve receber um castigo ou repreensão. Há um sentido social embutido nas definições de crime, uma vez que é um ato que "viola regras que a sociedade considera indispensáveis a sua existência" (CRIME, 2012, grifo nosso). Não se trata de uma violação apenas de cunho penal, mas também de outras ordens, como a moral e a ética.

As definições que acabamos de citar referem-se também a uma realidade jurídica de cada país, que estabelece suas próprias leis, e às transgressões destas, então não podemos deixar de levar em conta que o que é considerado crime em um país pode não o ser em outro. As leis são por definição suscetíveis à evolução, a serem melhor adequadas às necessidades de cada sociedade.

Ao longo do tempo, os motivos que levam uma pessoa a um crime foram estudados por várias áreas do conhecimento, da biologia à sociologia e à psicologia. Como, então, podemos 
abordar a noção de crime do ponto de vista da psicanálise e da noção de inconsciente? Se cada sociedade estabelece suas leis e regras (penais e morais) e, assim, seus crimes, a base inconsciente da transgressão de uma lei permanece, alterando-se apenas a percepção de cada um de quais atos representam transgressão. A partir desta ideia, como pensar o crime e as diferenças entre o homem e a mulher que podem levar um a cometer mais crimes do que o outro?

\section{O crime em psicanálise}

O crime, em Freud, está ligado ao sentimento de culpa. Na terceira parte do artigo "Alguns tipos de caráter encontrados no trabalho psicanalítico", intitulada "Criminosos em consequência de um sentimento de culpa", Freud (1916) escreve que, ao ouvir o que certas pessoas dizem sobre os atos interditos que cometeram durante a infância ou mesmo durante a vida adulta, percebeu que estas ações eram cometidas precisamente por serem interditas e até provocavam um alívio mental em seus autores. Ele notou um imenso sentimento de culpa de origem desconhecida nestes pacientes, que era atenuado pela passagem ao ato destas infrações. Esta culpa não viria após os atos interditos, mas ao contrário, estes seriam um produto deste sentimento de culpa. Estas pessoas poderiam ser consideradas como criminosos em consequência de um sentimento de culpa.

Freud (1916) argumenta que esta culpa vem do complexo de Édipo e representa uma reação às intenções criminosas de matar o pai e de ter relações incestuosas com a mãe. Os crimes cometidos pelos pacientes seriam uma tentativa de fixar em alguma coisa o sentimento de culpa que viria do desejo de cometer estes que são os dois grandes crimes humanos, intolerados desde as comunidades primitivas. O autor cita, então, as crianças que são propositalmente "travessas" para provarem o castigo e ficam quietas e satisfeitas com a punição, o que nos traz a ideia de um desejo de punição.

Esta motivação de crime nos adultos e o desejo de punição serão explicados a partir do texto "Dostoievski e o parricídio" (1928). Neste artigo, Freud volta a denominar o parricídio como crime primevo da humanidade, assim como do indivíduo, e fonte principal do sentimento de culpa, embora não a única. Ele prossegue para uma maior elaboração do tema através do complexo de Édipo, explicando que o relacionamento do menino com o pai é ambivalente; ele o vê como rival, mas também sente ternura por ele. Estas atitudes se combinam para produzir a identificação, uma vez que o menino deseja estar no lugar do pai porque o admira e quer ser como ele, mas também para tê-lo fora do caminho. Em algum momento a criança passa a compreender que o desejo de afastar o pai como rival será punido por ele com a castração. No interesse de preservar sua masculinidade, renuncia ao desejo de possuir a mãe e livrar-se do pai, mas este desejo permanece inconsciente e constitui a base do sentimento de culpa.

Freud (1928) atenta, porém, para uma diferença psicológica importante: o ódio pelo pai é abandonado devido à angústia de um perigo externo (a castração), enquanto que o enamoramento pelo pai é tratado como um perigo pulsional interno e que leva ao mesmo perigo 
externo. O que torna o ódio ao pai inaceitável é a angústia diante do pai. A castração é assustadora tanto como punição quanto como prêmio pelo amor, este último significando uma posição feminina como objeto de amor do pai. O recalque do ódio se dá por dois fatores: a angústia da castração e uma angústia diante da posição feminina. Isto faz com que uma forte predisposição bissexual venha condicionar ou reforçar a neurose.

Sendo assim, ainda para Freud (1928), a identificação com o pai constrói um lugar para si no ego, mas age em contraste com ele, o que é chamado de superego, e lhe são dadas as funções mais importantes como herdeiro da influência parental. Se o pai for duro e violento, o superego tende a assumir estas características contra o ego, que pode se tornar passivo, masoquista, de uma maneira feminina. Uma grande necessidade de punição surge no ego, que se oferece como vítima, mas também se satisfaz com os maus-tratos do superego, isto é, no sentimento de culpa. Toda punição é uma castração, o que realiza a antiga atitude passiva para com o pai.

Freud (1928) afirma ainda que existem grandes grupos de criminosos que desejam ser punidos, uma vez que o superego deles exige isso, poupando-se a si mesmos a necessidade de se infligirem o castigo. Neste ponto, elucida-se a teoria de Freud de que certos criminosos o são por um sentimento de culpa, uma vez que estes cometem pequenos delitos para encontrar um "recipiente" para este sentimento pré-existente, com uma exigência de punição de um superego severo.

Avançando nas contribuições da psicanálise para a criminologia, em uma conferência de Lacan e Cénac em 1950, publicada sob o título "Introdução teórica às funções da psicanálise em criminologia", Lacan (1950) retoma Freud ao sublinhar a importância do que ele chama de "primeira situação", que considera como a crise dramática que se resolve em estrutura „ crise esta que podemos entender como o complexo de Édipo e sua resolução que dá lugar à neurose, psicose ou perversão, e o crime em suas formas de incesto e parricídio. $\mathrm{O}$ autor concorda com a ideia de Freud de que o crime primordial, o parricídio, está na origem da Lei universal.

Lacan (1950) toma os elementos simbólicos reconhecidos na primeira ordem da delinquência como formas de exprimir as tensões do edipianismo, e escreve:

Essa referência sociológica do "caráter neurótico" concorda, de resto, com a gênese que dele fornece Kate Friedlander, se é exato resumi-la como a repetição, através da biografia do sujeito, das frustrações pulsionais que estavam como que detidas num curto-circuito na situação edipiana sem nunca mais se engajar numa elaboração estrutural (Lacan, 1950, pp. 136).

A passagem ao ato delituoso na delinquência constituiria, da mesma forma, uma revelação das tensões edipianas sobre as quais não se consegue realizar uma elaboração, repetidas em curto-circuito. Através dessa revelação, estas tensões poderiam ser dissipadas, o que parece ser uma finalidade da passagem ao ato. As frustrações pulsionais detidas num curto-circuito na situação edipiana buscam expressão, e sem a elaboração, buscam saída, seja no sintoma 
neurótico, ou na passagem ao ato.

Lacan (1966), no artigo "A agressividade em psicanálise", também retoma o termo pulsão de morte, de Freud, como estando no cerne da noção de agressividade, e afirma que há imagos representando vetores destas forças agressivas, como imagens de castração, mutilação, desmembramento, devoração etc. As intenções agressivas, sob qualquer pretexto, reatualizam estas imagos arcaicas e inconscientes no sujeito num outro em suas relações. Assim, quando houvesse a criação de um objeto criminogênico por parte do sujeito, por qualquer que fosse o pretexto, ele estaria investido com esta agressividade representada pelas imagos citadas.

Com o texto originalmente publicado em 1933, "Motivos do crime paranoico: o crime das irmãs Papin", Lacan (1933) faz uma breve análise de um crime cometido por duas irmãs que apresentavam sinais de psicose paranoica e assassinaram suas duas patroas, a mãe e a filha. Nesta que foi a tese de doutorado de Lacan em Psiquiatria em 1932, ele busca desenvolver suas ideias a respeito da pulsão agressiva na psicose e como esta pulsão atuou no caso das irmãs Papin.

A pulsão agressiva estaria, para Lacan (1933), na base da psicose, e se resolve no assassinato, mas como é inconsciente, significa que o conteúdo intencional que a traduz na consciência não pode se manifestar sem o compromisso com as exigências sociais. Estas exigências aparecem como o disfarce dos motivos, e é o que constitui todo o delírio. $O$ ato agressivo desfaz a construção delirante.

Neste caso, haveria ainda, como exposto por Lacan (1933), uma tendência homossexual da qual deriva a paranoia, e esta se expressa por uma negação apaixonada de si mesma, que estaria na base da convicção de ser perseguido e designaria o ser amado como perseguidor. Entre as irmãs haveria uma ambivalência afetiva, isto é, algo que surgiu na infância, da hostilidade primitiva entre irmãos que gera uma inversão anormal desta em desejo. 0 sujeito, então, transfere seu ódio amoroso para outras pessoas, que nada mais são do que imagens, inteiramente prisioneiras do narcisismo, de seu ideal. É um ódio de algo justamente porque representa seu ideal, e esta necessidade de autopunição e o sentimento de culpa também podem ser vistos no caso das irmãs Papin. Lacan escreve: "Na tarde fatídica, na ansiedade de uma punição iminente, as irmãs associam à imagem de suas patroas a miragem de seu mal. É sua aflição que elas detestam no par que arrebatam numa atroz quadrilha" (Lacan, 1933, pp. 390).

Podemos entender que o assassinato seria, então, uma satisfação da pulsão agressiva que está na base da psicose. Quando as irmãs Papin matam suas patroas, essa passagem ao ato busca por alívio à sua aflição e ansiedade, vindas, na verdade, dos processos da paranoia e da necessidade de autopunição e sentimento de culpa. Mas como podemos falar em sentimento inconsciente de culpa em uma estrutura que é marcada pela foraclusão da função paterna, noção posteriormente desenvolvida por Lacan, levando a uma defesa outra que não o recalque da pulsão parricida? Considerando a obra de Freud, isto não seria possível. Entretanto, deixaremos a questão 
sobre as diferenças entre a formação do sentimento de culpa na neurose e suas condições de possibilidade na psicose para serem exploradas em uma reflexão futura, mas observamos que mesmo na psicose, algo a que Lacan se refere como sentimento de culpa parece ser importante para os mecanismos psíquicos que levam a um crime, em especial o assassinato.

De qualquer forma, se tomarmos estas duas concepções, em Freud e em Lacan, podemos considerar que esta "necessidade de alívio" provoca o ato criminal que impulsiona o sujeito a uma satisfação através de uma passagem ao ato, direta, sem passar por uma simbolização, mecanismo que também parece se sustentar na psicose.

\section{"Totem e Tabu" e o complexo de Édipo Feminino}

A origem do sentimento de culpa é mais bem explorada em "Totem e Tabu", onde Freud (1913) afirma que ela estaria no desejo de parricídio e de incesto, a partir da alegoria da horda primitiva, onde havia um pai, um homem mais velho e mais poderoso que tomava para si todas as mulheres. Um dia, os filhos se rebelaram e mataram este pai, mas seus sentimentos por ele eram ambivalentes, eles o amavam também, o que gerou um sentimento de culpa e uma promessa de jamais repetir este ato, momento fundador da lei e da sociedade. No entanto, o desejo de cometer estes dois crimes permanece inconsciente. Freud (1913) associa esta alegoria ao surgimento das neuroses e ao complexo de Édipo.

Quando pensamos a alegoria da horda primitiva de Freud, também podemos nos perguntar: onde está a mulher? Há um pai mais velho e mais forte que guarda todas as mulheres para si, e os filhos que se rebelam e o matam para que possam tomar seu poder e todas as mulheres. Esta alegoria parece contar apenas para um sentimento de culpa que se desenvolve nos homens. Estes são homens que querem tomar as mulheres do pai para si, os homens que querem matar este Pai. A mulher aparece apenas na posição de objeto do desejo destes homens e de causa dos eventos que levam à morte do Pai e ao sentimento de culpa.

Quando Freud (1913) compara a vida dos primitivos com a vida dos neuróticos no estudo do surgimento das neuroses, ele especifica que tanto os meninos quanto as meninas chegam ao complexo de Édipo, e em um primeiro momento, os dois sustentam a mãe como objeto de amor e veem o pai como um rival que deve ser eliminado. No entanto, este processo vai em diferentes direções para a menina e o menino. Como podemos então pensar na formação do sentimento de culpa em ambos os sexos a partir do complexo de Édipo?

Em 1931, em um artigo intitulado "Sexualidade Feminina", Freud (1931) aborda muitos pontos importantes em relação ao complexo de Édipo feminino e como ele difere do masculino. 0 Édipo como originalmente formulado é caracterizado por uma criança que sente um grande amor pelo pai do sexo oposto e hostilidade em relação ao pai do mesmo sexo. No menino, isto parece fácil de conceber, já que o primeiro objeto de seu amor é sua mãe, de modo que, quanto melhor entende a relação que une sua mãe ao pai, mais tende a fazer deste seu rival. Na menina, o 
primeiro objeto do amor também é a mãe, mas, em certo momento, ela se afasta desta última e se aproxima de seu pai.

As mulheres só alcançariam uma situação normal, ou seja, uma situação edipiana positiva, depois de terem superado uma fase anterior governada por um complexo negativo. Freud escreve sobre esta fase: "De fato, durante essa fase, o pai de uma menina não é para ela muito mais do que um rival causador de problemas, embora sua hostilidade para com ele jamais alcance a intensidade característica dos meninos" (Freud, 1931, pp. 234, grifo nosso).

Se a hostilidade da menina para com seu pai nunca chega à mesma intensidade que a do menino, como isto influenciaria no sentimento de culpa nas meninas?

Freud (1931) acredita que a menina permanece em um forte vínculo com sua mãe por um longo tempo, e apenas em certo momento, ela se volta para o pai e desenvolve um sentimento de hostilidade para com a mãe. Para o menino, a mãe se torna o primeiro objeto de amor devido ao fato de alimentá-lo e de cuidar dele, e depois disso o objeto terá que ser substituído por alguém que se pareça com ela. Como as condições primárias para a escolha de objetos são as mesmas para todas as crianças, a mãe também se torna o primeiro objeto de amor da menina.

No entanto, Freud (1931) afirma que tem a impressão de que tudo o que ele postulou até então em sua teoria do complexo de Édipo se aplica apenas a crianças do sexo masculino, como evidenciado no seguinte trecho:

É apenas na criança do sexo masculino que encontramos a fatídica combinação de amor por um dos pais e, simultaneamente, ódio pelo outro, como rival. No caso dela, é a descoberta da possibilidade de castração, tal como provada pela visão dos órgãos genitais femininos, que impõe ao menino a transformação de seu complexo de Édipo (...) (Freud, 1931, pp. 237).

Esta descoberta, para Freud (1931), também leva à formação do superego, e após a internalização da autoridade paterna que marca o início do processo de inserção do indivíduo dentro da comunidade cultural, o superego é separado das figuras das quais constituía originalmente o representante psíquico, isto é, das figuras materna e paterna. É assim que o interesse narcisista do menino em preservar seus genitais se transforma em uma restrição à sexualidade infantil.

Ainda em Freud (1931), vemos que os efeitos do complexo de castração são, no entanto, diferentes na menina. Ela reconhece a sua castração, isto é, a superioridade do homem e sua própria inferioridade, e se rebela contra esse estado indesejável. É importante que ressaltemos que esta é uma interpretação imaginária para a diferença sexual e embora seja importante para o percurso da estruturação subjetiva, não é um "ponto final" e definitivo da mesma. O autor argumenta que uma das saídas possíveis para a menina é fazer do pai o objeto de seu amor e assim encontrar o caminho para o complexo de Édipo feminino. Nas mulheres, o Édipo não é destruído pelo complexo de castração, mas, pelo contrário, é criado por essa influência, e muitas 
vezes acontece que a mulher nunca o supere.

Freud (1931) também acrescenta que, precisamente por esta razão, as consequências culturais da dissolução do complexo de Édipo são menos numerosas e de menor magnitude na mulher. Esta observação é particularmente interessante para o nosso estudo, uma vez que é na resolução do complexo de Édipo que encontramos a mais significativa explicação para o sentimento de culpa responsável pelos crimes cometidos na idade adulta. A mulher não vive da mesma forma os processos de desenvolvimento que o homem experiencia, ela não resolve o complexo de Édipo com o complexo de castração, e como Freud aponta, muitas vezes ela não o resolve. De onde poderia vir o sentimento de culpa na mulher? Se não é o pai que é o principal objeto do crime cometido pela mulher, quem é?

Para desenvolver a questão da importância da fase pré-edipiana na mulher, Freud (1931) afirma que há uma atitude de hostilidade da garota para com a mãe que não é uma consequência da rivalidade do complexo de Édipo, mas vem da fase anterior e é reforçada na situação de Édipo. Esta transformação de um forte vínculo de amor em hostilidade ocorre devido a vários fatores. Um dos mais importantes é o fato de ver a mãe como castrada, o que a reduz a seus olhos, e o fato de culpá-la por não Ihe dar um pênis adequado, porque percebe que essa é uma característica da feminilidade.

$\mathrm{Na}$ conferência sobre a Feminilidade, Freud (1933) descreve mais especificamente que quando a distância da mãe ocorre, é mais do que apenas uma distância, mas o surgimento de um ódio contra a mãe. Ele escreve:

Esse passo no desenvolvimento não envolve apenas uma simples troca de objeto. 0 afastar-se da mãe, na menina, é um passo que se acompanha de hostilidade; a vinculação à mãe termina em ódio. Um ódio dessa espécie pode tornar-se muito influente e durar toda a vida; pode ser muito cuidadosamente super compensado, posteriormente. (Freud, 1933, pp. 122)

Este ódio contra a mãe, como explica Freud (1933), não só pode ser muito forte, mas também pode durar toda a vida, de modo que parte dele seja superada, mas outra parte persiste.

A inveja do pênis desempenha um papel crucial no desenvolvimento libidinal da menina e, por essa razão, para Freud (1933), a inveja e o ciúme desempenham um papel maior na vida mental das mulheres do que na dos homens. $O$ autor acrescenta que o amor da menina foi dirigido para uma mãe fálica. Quando ela descobre que sua mãe é castrada, torna-se possível abandoná-la como um objeto, e os impulsos hostis começam a dominar a situação.

No complexo de Édipo do menino, de acordo com Freud (1933), ele deseja sua mãe e quer eliminar seu pai, porque ele é um rival, algo que evolui naturalmente da fase da sexualidade fálica. No entanto, a ameaça de castração o obriga a abandonar essa atitude. Com o perigo de perder o pênis, o complexo de Édipo é reprimido, abandonado e, na maioria dos casos, completamente destruído, e um superego severo se instala como seu herdeiro. Para as meninas, o 
que acontece é o oposto; o complexo de castração prepara o caminho para o complexo de Édipo em vez de destruí-lo. A menina entra na situação edipiana como um refúgio do abandono do vínculo com a mãe influenciada pela inveja do pênis. Sem o medo da castração, a menina perde o principal motivo para abandonar o complexo de Édipo, e pode permanecer nesta situação indefinidamente ou destruí-lo de forma incompleta e tardia.

Quais são os efeitos desta diferença entre a resolução do complexo de Édipo feminino e masculino na formação do sentimento de culpa na menina? E na necessidade de autopunição que faz com que muitos criminosos cometam crimes para satisfazer esta necessidade?

O sentimento de culpa nas mulheres aparece no trabalho de Freud de 1921, intitulado "Psicologia de grupo e a análise do ego". Neste artigo, o autor discute a importância de identificar a formação de um sintoma neurótico de uma menina que reproduz o sintoma da mãe como resultado de um desejo hostil de tomar o lugar de sua mãe e que, sob a influência do sentimento de culpa, gera um sintoma em que ela sofre como a mãe. Ainda segundo Freud (1921), outro exemplo seria uma garota que viva um relacionamento proibido ou secreto e padece de sintomas histéricos por causa disso, o que leva suas amigas que também querem (ou vivem) uma situação semelhante a também terem crises histéricas, sob a influência do sentimento de culpa.

Podemos ver, a partir dessas considerações de Freud, que o sentimento de culpa nas mulheres é produzido por este desejo hostil de tomar o lugar da mãe, de maneira similiar ao menino em relação ao pai. Freud também aponta a importância da ansiedade gerada pela transgressão de uma regra da sociedade, ou pelo desejo de transgredir esta regra, como fator que produz sentimento de culpa. No entanto, a liberação de tais angústias nas mulheres parece ser geralmente sob a forma de um sintoma histérico, algo que se volta para si mesma, para o interior. Podemos pensar, a partir do explicitado anteriormente, que isto possa ser, de alguma forma, igualmente consequência de um recalcamento de instintos agressivos em mulheres, algo transmitido pelo social através dos chamados mecanismos da dominação masculina? Entendemos que este fator possua o risco de recair em um viés demasiadamente sociológico e não necessariamente psicanalítico, mas aqui também nos perguntamos acerca dos limites da influência do social na constituição do psíquico e no destino da agressividade feminina.

Sabemos que, para a psicanálise, o crime é o resultado de um sentimento de culpa que vem do desejo de cometer incesto e parricídio. No entanto, como observa Freud, o desejo de parricídio e incesto não são as únicas fontes de culpa, e sabemos que as mulheres também o têm, mas podemos dizer que o sentimento de culpa que impulsiona ao crime nas mulheres pode não ser tão intenso quanto nos homens? Afinal, sua rivalidade para com o pai nunca atinge a intensidade da rivalidade do menino com seu pai e ela desenvolve um ódio contra a mãe que o menino não chega a desenvolver e que influencia seu desenvolvimento libidinal de outras maneiras. Assim, o objeto criminogênico da mulher seria a mãe e não o pai, uma vez que na situação edipiana, ela pretende eliminar a mãe e ocupar seu lugar ao lado do pai? No entanto, 
uma mulher nunca pode superar completamente o complexo de Édipo, de modo que a forte supressão dos desejos que geram o sentimento de culpa no menino nunca pode nunca acontecer completamente na garota.

Outro fator importante a se refletir sobre esta questão é que mesmo a hostilidade da mulher contra a mãe não parece assumir proporções criminogênicas, como o ódio contra o pai assume no menino. Assim, podemos considerar como um dos fatores a serem levados em conta no estudo da diferença entre o número de homens e mulheres que cometem crimes em geral, a diferença na constituição do sentimento de culpa nas mulheres, para além de um recalcamento de seus impulsos agressivos, este último um fator que nos leva a questionar onde se encontram e onde se separam o social e o psíquico e psicanalítico.

\section{A dominação masculina e a diferença sexual no inconsciente}

A propósito deste recalcamento dos impulsos agressivos da mulher, não podemos deixar de mencionar Bourdieu e sua obra intitulada "A dominação masculina", de 1998. Nesta obra, o autor discute esta dominação pelo homem, uma ordem masculina patriarcal da qual as mulheres são vítimas, que é produzida e se reproduz na ordem simbólica do social, tendo efeitos diretamente sobre os corpos socializados. Na dominação masculina, vemos uma submissão paradoxal, que Bourdieu (1998) considera um efeito do que ele chama de violência simbólica, uma violência doce, insensível e invisível para suas vítimas, que é exercida pela via essencialmente simbólica da comunicação e do conhecimento. Esta dominação seria perpetuada sobretudo pelas instituições como a Igreja e o Estado, assim como pela família, como escreve Bourdieu:

Se é verdade que o princípio da perpetuação desta relação de dominação não reside verdadeiramente, ou em todo caso principalmente, num dos lugares mais visíveis de seu exercício, isto é, no seio da unidade doméstica, sobre a qual certos discursos feministas tem concentrado todas as suas atenções, mas nas instâncias tais como a Escola e o Estado, lugares de elaboração e de imposição dos princípios de dominação que se exercem no próprio seio do universo mais privado, é um campo de ação imensa que se encontra aberto às lutas feministas, assim chamadas a tomar um lugar original, e bem afirmado, no seio das lutas políticas contra todas as formas de dominação (Bourdieu, 1998, pp. 15, tradução nossa).

As estruturas de dominação, como argumenta Bourdieu (1998), são produtos de um trabalho incessante, histórico, de reprodução, ao qual contribuem os agentes naturais (os homens com as armas como a violência física e a violência simbólica e as instituições mencionadas anteriormente, como a família, a Igreja, o Estado, a escola etc.). Os dominados aplicam as categorias construídas a partir do ponto de vista dos dominantes às relações de dominação, logo elas aparecem como naturais. A violência simbólica é instituída uma vez que o dominado não pode estar em desacordo com o dominante porque não tem os instrumentos de conhecimento para 
pensar esta relação, o que a faz natural.

Bourdieu (1998) aborda também a relação entre a virilidade e o exercício da violência:

A virilidade, entendida como capacidade reprodutiva, sexual e social, mas também como aptidão ao combate e ao exercício da violência (na vingança particularmente), é antes de tudo um fardo. Ao contrário da mulher, cuja honra, essencialmente negativa, só pode ser defendida ou perdida, sua virtude sendo sucessivamente a virgindade e a fidelidade, 0 "homem de verdade" é que aquele que se sente tomado a estar à altura da possibilidade que lhe é oferecida de aumentar sua honra buscando a glória e a distinção na esfera pública. A exaltação dos valores masculinos tem sua contrapartida tenebrosa nos medos e nas angústias que suscitam a feminilidade: as fraquezas e princípios de franqueza enquanto encarnações da vulnerabilidade da honra" (Bourdieu, 1998, pp. 75-76, tradução nossa).

Tudo isso, para Bourdieu (1998), faz do ideal impossível da virilidade algo de enorme vulnerabilidade, o que conduz ao investimento em todos os jogos de violência masculina, tais como os esportes, em particular aqueles que são feitos para produzirem símbolos de masculinidade, ou esportes de combate. Esta honra e virilidade também devem ser reconhecidas pelos outros homens, e em nome desta virilidade, um grande número de homens se engajam nos grupos de rituais do sexo masculino, até mesmo nos grupos de criminosos, e nos estupros coletivos. Eles também se envolvem com os rituais da Polícia e do Exército. Trata-se de um medo de cair numa "fraqueza" feminina e não ser reconhecido como viril pelo grupo.

É claro que não podemos deixar de observar que toda esta estrutura social do "papel da mulher" e do "papel do homem" que Bourdieu descreve vem mudando e sendo aos poucos descontruída na sociedade, principalmente a partir de 1968, com movimentos feministas que buscam a igualdade de gênero. Podemos nos perguntar que efeitos estas mudanças já vêm trazendo e vão trazer a longo prazo para a constituição psíquica tanto feminina quanto masculina.

Assim, se levarmos em conta a estrutura social que reproduz a dominação masculina, e que toma a violência por manifestações de potência e de virilidade masculinas esperadas pela sociedade, podemos pensar na forma como estas configurações sociais levam os homens a mais crimes violentos. Este sistema espera um homem ativo, dominante e violento em certas situações, e espera uma mulher passiva e submissa à dominação, o que pode também inibir sua própria agressividade, levando-as a cometer menos crimes violentos que os homens.

A linha de argumentação de Bourdieu sobre a dominação masculina é, para nós, válida e traz uma contribuição e um questionamento importantes ao nosso estudo sobre o crime para o homem e para a mulher, a respeito dos limites da influência do social sobre o psíquico. Porém, trata-se de um viés sociológico que não leva em conta a diferenciação sexual no inconsciente. André (1986), em "O que quer uma mulher?", nos mostra que na obra de Freud a descoberta das diferenças anatômicas é apenas parte de um processo de diferenciação, e que a pulsão sexual se 
organiza em torno de polarizações que o autor chama de fundamentalmente assexuadas, que são a passividade-atividade e sujeito-objeto, e não em torno do casal macho-fêmea. André (1986) escreve que "do ponto de vista do inconsciente, a atração recíproca entre macho e fêmea é uma questão, não um dado a priorl" (pp. 19, grifo do autor).André (1986) ainda explica que na oposição entre passividade e atividade se atribuem à libido dois modos de satisfação diferentes, dos quais um corresponderia a um caráter feminino (passividade) e o outro mais a um caráter masculino (atividade). Seriam dois modos de gozo, ativo e passivo, para uma libido única. A outra oposição situa-se por relação ao tipo de objeto sobre o qual se apoia a satisfação, entre a libido do ego e a libido objetal, ou seja, em relação à libido investida no ego ou em um objeto externo. Para André (1986), Freud não se apoia numa clivagem entre dois sexos, mas na inscrição no próprio sujeito do inconsciente de uma divisão que se introduz com a sexualidade, e afirma: "Freud constata que a diferença de órgãos apresentada pelo corpo humano não se significa, ao nível do inconsciente, como uma divisão entre dois sexos" (p. 21).

André (1986) ainda apresenta a contribuição do ensino de Lacan à diferenciação sexual no inconsciente ao apontar que este autor recoloca a questão da libido a partir de uma divisão, mas do ponto de vista do gozo, se questionando se haveria um gozo próprio à mulher. O ponto em que Lacan chega, então, é, segundo André (1986): "a divisão entre dois tipos de gozo - um interditado pelo significante e ligado ao próprio ser, e outro permitido pelo significante e ligado à significação fálica" (pp. 26). Desta forma, entendemos que quando falamos em diferenciação sexual à nível do inconsciente, não estamos falando de uma divisão entre dois sexos ou dois gêneros, mas em termos de divisões na libido e no gozo.

Freud também teceu alguns comentários a respeito da sexualidade masculina como sendo ligada à agressão, assim como a noção de pulsão agressiva, como veremos a seguir. No artigo "Três ensaios sobre a teoria da sexualidade", publicado em 1905, ele descreve o desejo de fazer o objeto sexual sofrer como sadismo e como masoquismo a tendência inversa, considerando-os como a forma mais difundida e mais importante da perversão. Podemos encontrar as origens do sadismo na vida normal, particularmente na sexualidade do homem, que comportaria uma quantidade de agressão, possivelmente explicada na biologia pela necessidade de vencer a resistência do objeto sexual ao mesmo tempo em que o corteja. Assim, em Freud (1905), a sexualidade do homem tem uma tendência à agressão, enquanto que a sexualidade da mulher não possui este caráter agressivo.

Entretanto, ainda nos Três ensaios, Freud (1905) sustenta que a história da civilização nos mostra que a crueldade e a pulsão sexual são firmemente unidas, o que traz um elemento agressivo para o conceito de libido, que poderia estar ligado, como alguns autores o consideram, aos resíduos dos apetites canibais. Este elemento de crueldade determina uma parte da atitude social do paciente a respeito dos sintomas das psiconeuroses, provocando a transformação do amor em ódio e das emoções afetivas em movimentos hostis. Podemos também encontrá-lo nos 
sintomas da neurose e da paranoia, como vimos anteriormente em Lacan e no caso das irmãs Pappin.

Esta mesma crueldade que provoca a transformação do amor em ódio e que está firmemente ligada à pulsão sexual estaria presente desde a infância, e neste ponto, Freud (1905) não faz nenhuma restrição de gênero a respeito da existência da mencionada crueldade, assim como Lacan também não o faz no texto "A agressividade em psicanálise". Em Três ensaios, Freud afirma que podemos encontrar na sexualidade da criança os componentes que precedem à escolha dos outros como objetos sexuais, e entre estes componentes, encontramos também aqueles que levam às crianças a serem voyeurs e exibicionistas, assim como a pulsão da crueldade. Esta, enquanto fator componente da vida sexual, se desenvolve independentemente da vida sexual ligada às zonas erógenas.

Sobre esta pulsão, Freud (1905) escreve que podemos admitir que a tendência à crueldade deriva da pulsão de dominar, e que ela aparece na vida sexual numa fase que será descrita como uma organização pré-genital, em que os genitais ainda não tem um papel definido. Ele também aponta que as crianças que possuem uma tendência à crueldade com os animais e com os amigos são geralmente os primeiros a conhecerem as atividades intensas e precoces das zonas erógenas. A ausência da vergonha, que só é desenvolvida mais tarde, traz um perigo: de que a ligação entre a atividade erótica e a crueldade se tornem indissolúveis.

Retornando à conferência sobre a Feminilidade, Freud (1933) explica que não observamos nenhum abrandamento da agressividade na fase sádico-anal das meninas e que suas pulsões agressivas não são menos numerosas ou mais fracas que as dos meninos, de modo que: "Com seu ingresso na fase fálica, as diferenças entre os sexos são completamente eclipsadas pelas suas semelhanças. Nisto somos obrigados a reconhecer que a menininha é um homenzinho" (Freud, 1933, pp. 118).

Assim, podemos considerar que os dois sexos, as meninas e os meninos, possuem esta "agressividade originária" desde os primeiros anos da infância, porém na mesma conferência, Freud (1933) ressalta a importância dos costumes sociais que obrigam a mulher a assumir uma posição passiva:

Existe uma relação particularmente constante entre feminilidade e vida instintual, que não devemos desprezar. A supressão da agressividade das mulheres, que lhes é instituída constitucionalmente e Ihes é imposta socialmente, favorece o desenvolvimento de poderosos impulsos masoquistas que conseguem, conforme sabemos, ligar eroticamente as tendências destrutivas que foram desviadas para dentro. (Freud, 1933, pp. 116-117)

Neste ponto, Freud (1933) também parece atribuir às regras sociais, e podemos dizer, à dominação masculina, algo de importante no que concerne à repressão das pulsões agressivas nas mulheres, que desenvolvem poderosos impulsos masoquistas. Se levarmos em conta que as pulsões agressivas das mulheres são reprimidas e socializadas, podemos pensar que esta constitui 
uma das razões pelas quais as mulheres cometem menos crimes do que os homens.

Entretanto, falamos de forma semelhante de crianças de ambos os sexos que possuem pulsões agressivas. Devido à uma repressão destas pulsões na mulher causada por uma ordem social, elas passariam a dirigir esta agressividade a si próprias e a assumir uma posição passiva, embora devamos também lembrar que o crime não passa somente pela via da agressividade. Há uma ideia de transgressão que, como discutido anteriormente, está ligada ao sentimento de culpa pelos desejos inconscientes de parricídio e incesto e uma busca por alívio do mesmo através dos crimes cometidos, uma necessidade de um crime real por onde escoar esse sentimento de culpa. Logo, não se trata apenas de crimes violentos como os assassinatos cometidos por conta de instintos agressivos mais ou menos socialmente reprimidos ou em nome de uma ordem social, mas de crimes de todos os tipos, com ou sem violência, que ocorrem numa tentativa de dar conta de um sentimento de culpa. Da mesma forma, não buscamos afirmar que a passividade em geral mais ligada ao feminino seja um resultado unicamente de um recalque de pulsões agressivas. A passividade e a atividade no inconsciente, como já vimos, tem a ver com uma divisão da satisfação da libido em dois modos.

Sendo assim, se tomarmos as diferenças entre o complexo de Édipo feminino e o masculino e como a formação do sentimento de culpa em ambos os sexos é diferente, podemos pensar que como a menina nunca alcança o mesmo nível de ódio pelo pai e redireciona seu desejo pela mãe antes de entrar no Édipo, muitas vezes nem mesmo chegando a resolvê-lo, as principais fontes do sentimento de culpa que levam ao crime podem não ser tão intensas na menina. Desta forma, poderíamos encontrar aí um dos motivos pelos quais as mulheres cometem menos crimes do que os homens.

\section{Conclusão}

O objetivo deste estudo foi apresentar uma nova perspectiva, a da psicanálise, à questão da diferença entre o número de homens que cometem crimes em relação ao de mulheres que o fazem. À primeira vista temos os argumentos sociológicos, os mais comumente difundidos, que consideramos importantes, como o da dominação masculina descrita por Bourdieu, e também o da sexualidade do homem, geralmente relacionada à agressão. 0 próprio Freud traz esta ligação entre o social e o psíquico ao teorizar que a agressão nas mulheres é socialmente reprimida e consequentemente recalcada, de modo que seus impulsos hostis são eventualmente empurrados para dentro, gerando sintomas histéricos e colocando as mulheres em uma posição passiva.

No entanto, a psicanálise traz também uma outra maneira de pensar a criminologia. 0 crime, para Freud e Lacan, é devido a um sentimento de culpa engendrado pelo desejo de cometer parricídio e incesto, os dois crimes primitivos da humanidade que permanecem inconscientes durante toda a vida. Os crimes seriam uma tentativa de fixar este sentimento de culpa em algo, a fim de obter uma penalidade real, o que gera alívio. Mas se tomarmos o complexo de Édipo, 
responsável pela formação do superego e crucial para o surgimento do sentimento de culpa, vemos que ele não está constituído da mesma forma em mulheres e homens. Ambos têm sentimento de culpa, mas as diferenças na resolução do complexo de Édipo do menino e da menina podem afetar a formação deste sentimento de maneiras diferentes. Uma garota, talvez, nunca possa desenvolver o sentimento de culpa que a incitaria ao crime de forma tão intensa como o menino e isso pode ser uma das razões pelas quais as mulheres cometem menos crimes, que não necessariamente passam apenas pela via da agressão, podendo ser transgressões da lei de todo tipo, violentas ou não.

Para pesquisas futuras, sugerimos uma melhor reflexão sobre o sentimento de culpa e sua relação com crimes na perversão e na psicose, já que este estudo tratou desse objeto com um foco direcionado às neuroses e, como visto no estudo de Lacan sobre o crime das irmãs Papin, há semelhanças nos mecanismos do crime entre as diferentes estruturas.

\section{Notas}

1. Este artigo foi extraído e adaptado de minha dissertação de Master em Psychologie (Psychanalyse et recherches interdisciplinaires) na Université Paris-Diderot (Paris VII), intitulada Le crime passionnel: sur la culpabilité chez l'homme et chez la femme, originalmente parte do programa de Master 2 Recherche (M2R), sob orientação do Prof. Dr. Paul-Laurent Assoun, no ano de 2015.

\section{Referências Bibliográficas}

André, S. (1986) O que quer uma mulher?. Rio de Janeiro: Jorge Zahar Ed.. Bourdieu, P. (1998) La domination masculine. Paris: Seuil.

Crime. Moderno Dicionário da Língua Portuguesa Online. Recuperado: 22 de agosto de 2012. Disponível: http://michaelis.uol.com.br/

Fernandes, W. (2015) População Carcerária feminina aumentou 567\% em 15 anos no Brasil. Conselho Nacional de Justiça. Recuperado: 17 de abril de 2018. Disponível: http://www.cnj.jus.br/noticias/cnj/80853-populacao-carceraria-feminina-aumentou-567-em-15anos-no-brasil

Ferreira, A. B. H. (2008) Dicionário da Língua Portuguesa Aurélio. Curitiba: Positivo.

Freud, S. (2006). Alguns tipos de caráter encontrados no trabalho psicanalítico: (III) Criminosos em consequência de um sentimento de culpa. In J. Salomão (Trad.) Edição Standard Brasileira das Obras Psicológicas Completas de Sigmund Freud (Vol. 14, pp. 375-377) Rio de Janeiro: Imago. (Trabalho original publicado em 1916).

Freud, S. (1928). Dostoievski e o parricídio. In J. Salomão (Trad.) Edição Standard Brasileira das Obras Psicológicas Completas de Sigmund Freud (Vol. 21, pp. 201-227). Rio de Janeiro: Imago. (Trabalho original publicado em 1928). 
Freud, S. (2006). Totem e Tabu. In J. Salomão (Trad.) Edição Standard Brasileira das Obras Psicológicas Completas de Sigmund Freud (Vol. 13, pp. 13-162). Rio de Janeiro: Imago. (Trabalho original publicado em 1913).

Freud, S. (2006). Sexualidade Feminina. In J. Salomão (Trad.) Edição Standard Brasileira das Obras Psicológicas Completas de Sigmund Freud (Vol. 21, pp. 231-251). Rio de Janeiro: Imago. (Trabalho original publicado em 1931).

Freud, S. (2006). Feminilidade. Novas Conferências Introdutórias XXXIII. In J. Salomão (Trad.) Edição Standard Brasileira das Obras Psicológicas Completas de Sigmund Freud (Vol. 22, pp. 113-134). Rio de Janeiro: Imago. (Trabalho original publicado em 1933).

Freud, S. (2006). Psicologia de grupo e a análise do ego. In J. Salomão (Trad.) Edição Standard Brasileira das Obras Psicológicas Completas de Sigmund Freud (Vol. 18, pp. 79-154). Rio de Janeiro: Imago. (Trabalho original publicado em 1921).

Freud, S. (1905). Três ensaios sobre a teoria da sexualidade. In J. Salomão (Trad.) Edição Standard Brasileira das Obras Psicológicas Completas de Sigmund Freud. (Vol. 7, pp. 119-229). Rio de Janeiro: Imago. (Trabalho original publicado em 1905).

Lacan, J.; Cénac, M. (1998). Introdução teórica às funções da psicanálise em criminologia. In J. Lacan, Escritos (pp. 127-151). Rio de Janeiro: Jorge Zahar. (Trabalho original publicado em 1966. Conferência proferida em 1950).

Lacan, J. (1998). A agressividade em psicanálise. In J. Lacan, Escritos (pp. 104-126). Rio de Janeiro: Jorge Zahar. (Trabalho original publicado em 1966)

Lacan, J. (1987). Motivos do crime paranóico: o crime das irmãs Papin. In J. Lacan, Da psicose paranóica em suas relações com a personalidade seguido de primeiros escritos sobre a paranóia (pp. 381-390). Rio de Janeiro: Forense-Universitária. (Trabalho original publicado em 1933) Rodriguez, M. (2016) Por que os homens são responsáveis por 95\% dos homicídios no mundo?. $B B C$ Brasil. Recuperado: 17 de abril de 2018. Disponível: http://www.bbc.com/portuguese/internacional-37730441, http://www.bbc.com/portuguese/internacional-37730441.

Citacão/Citation: Dos Santos, V. T. (mai. 2018 a out. 2018). O crime: sobre o sentimento de culpa no homem e na mulher. Revista aSEPHallus de Orientação Lacaniana, 13(26), 134-149. Disponível em www.isepol.com/asephallus. Doi: 10.17852/1809-709x.2019v13n26p134-149.

Editor do artigo: Tania Coelho dos Santos.

Recebido/Received: 03/01/2019 / 01/03/2019.

Aceito/Accepted: 12/03/2019 / 03/12/2019.

Copyright: ( 2019 Associação Núcleo Sephora de Pesquisa sobre o moderno e o contemporâneo. Este é um artigo de livre acesso, que permite uso irrestrito, distribuição e reprodução em qualquer meio, desde que o autor e a fonte sejam citados/This is an open-access article, which permites unrestricted use, distribution, and reproduction in any medium, provided the author and source are credited. 